\title{
Peruwiański eksperyment. Pomoc rozwojowa poprzez współpracę wielu podmiotów z organizacją pozarządową jako liderem
}

\begin{abstract}
Streszczenie
Artykuł ten jest studium przypadku roli, jaką odgrywa organizacja pozarządowa w polityce rozwojowej i pomocy rozwojowej na przykładzie działalności Fundacji Coprodeli w Peru. W rozwiniętych państwach demokratycznych organy władzy państwowej realizację części swoich zadań przekazują organizacjom społeczeństwa obywatelskiego. Jednak organizacje te mogą także stać się liderem polityki rozwoju, zastępując lub wspierając państwo. Ustalenie to jest szczególnie istotne w perspektywie krajów rozwijających się. Jednak model działalności tych organizacji musi być włączający, a nie zastępujący. Wypracowany przez Coprodeli model angażuje zarówno beneficjentów, lokalne i państwowe struktury władzy i biznesu, jak i inne organizacje pomocowe. Współuczestnictwo wielu podmiotów i specyfika pracy fundacji, która stawia całe osiedla w miejscach zaniedbanych i dotkniętych klęskami żywiołowymi, sprawiają, że model wypracowany przez Coprodeli jest ważny dla rozwoju teorii polityki pomocy rozwojowej.
\end{abstract}

Słowa kluczowe: Peru, pomoc rozwojowa, organizacje pozarządowe, dysfunkcja państwa, Coprodeli

\section{The Peruvian experiment. Developmental aid as a result of cooperation of many agencies with a non-governmental organisation as the leader}

\begin{abstract}
This article is a case study of the role played by a non-governmental organisation in the development policy and development assistance on the example of the Coprodeli Foundation in Peru. In developed democratic countries, the organs of state power entrust part of their tasks to civil society organisations. However, these organisations can also become
\end{abstract}

1 Kolegium Ekonomiczno-Społeczne, Szkoła Główna Handlowa w Warszawie 
the leader in the development policy replacing or supporting the state. This determination is particularly important in the perspective of developing countries. However, the business model of these organisations must be inclusive and not substitute. The model developed by Coprodeli involves both beneficiaries, local and state power and business structures, and other aid organisations. Participation of many entities and the specifics of the work of the foundation, which places entire settlements in places neglected and affected by natural disasters, makes the model developed by Coprodeli important for the advancement of the theory of development assistance policy.

Keywords: Peru, development aid, non-governmental organisations, state disfunction, Coprodeli

W aktualnej sytuacji międzynarodowej kwestie związane z pomocą rozwojową stały się częstym i istotnym tematem dyskursu publicznego. Ich wagę uwidoczniły problemy związane z wojnami i migracjami (m.in. kryzys migracyjny w Europie), a praktyczne wdrażanie rozwiązań, wynikających z jej stosowania, pokazało, przed jak dużymi wyzwaniami stoimy. W zglobalizowanym świecie państwa, funkcjonując w ramach organizacji międzynarodowych, unii i sojuszy (jak np. Unia Europejska), często wspólnie realizują polityki publiczne, wykraczające poza ich granice państwowe, np. w zakresie pomocy rozwojowej. Powodzenie realizacji wspólnej zewnętrznej polityki z dziedziny rozwojowej jest uzależnione nie tylko od współpracy pomiędzy państwami prowadzącymi tę politykę, ale także od kooperacji z organizacjami społeczeństwa obywatelskiego (zarówno międzynarodowymi, jak i lokalnymi), z organami państw, której ta pomoc dotyczy, jak i ze społecznościami lokalnymi, dla których ta pomoc jest przeznaczona. Pomoc rozwojowa świadczona jest przez państwa i organizacje międzynarodowe na rzecz państw mniej rozwiniętych, w tym tych, których rozwój jest dotknięty dysfunkcją, zarówno czasową, będącą efektem np. katastrof naturalnych, czy trwałą, wynikającą m.in. z działań wojennych, uwarunkowań geograficznych czy ekonomicznych. Należy ją odróżniać od polityki rozwoju, która jest prowadzona przez wewnętrzne w danym państwie podmioty sfery publicznej.

Organizacje społeczeństwa obywatelskiego są bardzo ważnym partnerem władz publicznych zarówno w zakresie polityki pomocy rozwojowej, jak i polityki rozwoju, a także generalnie w polityce publicznej, którą rozumiem jako działania państwa mające skutki dla obywateli (Arczewska, 2011:3). W rozwiniętych państwach demokratycznych organy władzy państwowej realizację części swoich zadań przekazują organizacjom społecznym. W Polsce kwestię tę reguluje Ustawa o działalności pożytku publicznego i o wolontariacie z dnia 24 kwietnia 2003 r., a organizacje pozarządowe 
wykonują część zadań publicznych w obszarach takich jak ochrona środowiska, sprawy społeczne (np. pomoc dla osób bezdomnych, pomoc dla dzieci i rodzin w kryzysie, pomoc osobom z zaburzeniami psychicznymi, KLON/JAWOR, 2002: 15) oraz kultura (Obłąkowska-Kubiak, 2014: 266-267). Jednak w państwach zaliczanych do grupy rozwijających się organizacje pozarządowe, nierzadko wywodzące się z innych państw, mogą się stać liderem polityki rozwoju, wspierając te państwa w walce z najtrudniejszymi problemami ich społeczeństw, takimi jak ubóstwo, bezdomność, bezrobocie, brak dostępu do opieki zdrowotnej i edukacji.

W niniejszym artykule przedstawiam sytuację, jaka istnieje w Republice Peru, w której organizacja społeczna o nazwie Fundacja Coprodeli jest liderem polityki rozwoju i realizuje pomoc rozwojową. Rozdział rozpoczyna się od krótkiej definicji w celu rozróżnienia pomocy rozwojowej od polityki rozwoju. Następnie przedstawiono sytuację w Peru, zarówno ekonomiczną, jak i społeczną, zwłaszcza dotyczącą zjawiska migracji i polityki mieszkaniowej, oraz dokonano przeglądu teorii dotyczących pomocy rozwojowej. Dalej zarysowana została historia powstania Fundacji Coprodeli i rzecz najistotniejsza, czyli model jej działania. Rozdział ten jest studium przypadku roli, jaką odgrywa organizacja pozarządowa w polityce rozwoju i pomocy rozwojowej na przykładzie działalności Fundacji Coprodeli w Peru.

\section{Pomoc rozwojowa a polityka rozwoju}

Pomoc rozwojowa jest to pomoc świadczona przez państwa i organizacje międzynarodowe w formie finansowej, materialnej i doradczej na rzecz państw mniej rozwiniętych, mająca na celu redukcję ubóstwa, zwiększenie bezpieczeństwa, zmniejszenie nierówności i bezrobocia, wspieranie reform demokratycznych i rządów prawa, przestrzegania praw człowieka, rozwój społeczeństwa obywatelskiego, promocję zrównoważonego rozwoju, wspieranie wzrostu gospodarczego, zapobieganie konfliktom oraz promocję bezpieczeństwa globalnego, rozwiązywanie problemów dotyczących ochrony środowiska i klimatu. (Zygierewicz, 2017: 8; Mirkowska-Ostatek, 2013: 56). Jest ona czymś innym niż polityka rozwojowa, która jest prowadzona przez podmioty sfery publicznej wewnętrznie w danym państwie, choć ich cele są zbieżne.

Polityka rozwoju to konglomerat wzajemnie powiązanych działań podejmowanych i realizowanych przez organy publiczne (w Polsce: Radę Ministrów, samorząd województwa, związki metropolitarne, samorząd powiatowy i gminny) w celu zapewnienia trwałego i zrównoważonego rozwoju kraju, spójności społeczno-gospodarczej, regionalnej i przestrzennej, podnoszenia konkurencyjności gospodarki oraz tworzenia 
nowych miejsc pracy w skali krajowej, regionalnej lub lokalnej (Dz.U. 2016). Jest to działalność państwa na swoim terytorium, która prowadzona jest w wyznaczonych z góry ramach finansowych i politycznych.

\section{Peru - krótka charakterystyka państwa}

Republika Peru jest trzecim pod względem wielkości terytorium państwem na kontynencie południowoamerykańskim, po Brazylii i Argentynie, oraz dziewiętnastym w tej kategorii na świecie. Liczba ludności przekroczyła $33 \mathrm{mln}$ osób, a powierzchnia terytorium wynosi $1,3 \mathrm{mln} \mathrm{km}^{2}$. Jest to więc państwo czterokrotnie większe od Polski, ale $\mathrm{z}$ mniejszą liczbą ludności. W efekcie gęstość zaludnienia jest aż pięciokrotnie niższa ( 24 osoby na $\mathrm{km}^{2}$ ) niż w Polsce (124 osoby na $\mathrm{km}^{2}$ ), ale i tak wyższa niż w sąsiednim Chile - 21 os. $/ \mathrm{km}^{2}$ (The World Bank, 2016). Terytorium państwa peruwiańskiego jest zróżnicowane pod względem geograficznym i klimatycznym, a rozległe obszary kraju są trudne do zamieszkiwania, np. pasma wysokogórskie w Andach czy las równikowy. Wybrzeże oceaniczne często nawiedzane przez trzęsienia ziemi miejscami ma charakter pustynny i półpustynny, a ludzkie skupiska znajdują się zazwyczaj wzdłuż rzek bądź na wybrzeżu. Według danych z 2017 r. 11,15 mln obywateli Peru mieszka w stolicy państwa Limie (World Bank, 2019).

Ostatnie 25 lat to w Peru czas rozwoju gospodarczego, co widać we wzroście PKB oraz wskaźnika Human Development Index (HDI), a do państwa przylgnęła nazwa: „andyjski tygrys”. PKB per capita w parytecie siły nabywczej wzrósł z 3,4 tys. w 1990 r. do 13 tys. w 2016 r., a w USD z poziomu 1,2 tys. w 1990 r. do poziomu 6 tys. w 2016 r. (The World Bank, 2017). Nie jest to wzrost tak szybki jak w Chile, które od drugiej połowy lat 80. XX w. do 2003 r. było najszybciej rozwijającym się krajem Ameryki Południowej (Łyniewska, 2010: 216), ale jest znaczący. W ciągu ostatniego dziesięciolecia z grona mieszkańców Peru dotkniętych skrajną biedą wypadła aż jedna trzecia ludności: odsetek z 59 proc. w 2004 r. spadł do niespełna 26 proc. w 2012 r. (Komisja Europejska, 2014: 6). HDI w 1990 r. wynosił w Peru 0,613, a w 2015 r. 0,740, co dało temu państwu 87. miejsce na świecie. Dla porównania w Chile w 1990 r. wskaźnik ten miał poziom 0,700, a w 2015 r. 0,847, co dało globalnie 38. pozycję. W Norwegii, która znajduje się na 1. miejscu listy według wysokości tego wskaźnika jakości życia, w 1990 r. wynosił on 0,849, a w 2015 r. 0,949, zaś w Polsce (36. miejsce na świecie) w 1990 r. 0,712, a w 2015 r. 0,855 (UNDP, 2017).

W Peru dwie dekady temu tzw. pierwsze 10 proc. obywateli, czyli grupa o najwyższym dochodzie w państwie, dysponowało 35,4 proc. globalnego przychodu, a poszerzając o kolejną grupę - tzw. górne 20 proc. miało do dyspozycji blisko 52 proc. dochodu. 
W 2013 r. proporcje te uległy nieznacznej poprawie: na pierwsze 10 proc. przypadało 33,4 proc. globalnego dochodu, a na pierwsze 20 proc. 49,7 proc. dochodu. To lepsze wskaźniki niż w Chile, gdzie pierwsze 10 proc. osiąga 41,4 proc. całego dochodu, a pierwsze 20 proc. odpowiada za 56,7 proc. dochodu (World Bank, 2019). Mimo to oficjalnie społeczeństwo peruwiańskie może pochwalić się niską stopą bezrobocia, wynoszącą 4,2 proc., a tylko w 31 społeczeństwach na świecie jest ona niższa (ILO, 2019). Bezdomność dotyka w Peru 5,6 proc. populacji (UN, 2019), a dostęp do usług publicznych ma 76,2 proc. Peruwiańczyków, co jest wzrostem z 52,8 proc. w $1990 \mathrm{r}$. W Chile statystyki wskazują odpowiednio: 0,7 proc. osób bezdomnych, a dostęp do usług publicznych 99,1 proc. ludności (UN, 2019). Bank Światowy i Międzynarodowy Fundusz Walutowy szacują, że tempo wzrostu na poziomie 6-procentowych przyrostów PKB pozwoli Peru wyprzedzić pod kątem wskaźników ekonomicznych sąsiednią Boliwię i Ekwador, ale nadal trudno będzie doścignąć Chile i Kolumbię (International Monetary Found, 2019).

\section{Migracje w Peru i ich znaczenie}

Rozwój gospodarczy Peru lat 1950-1975 wywołał nasilone migracje wewnętrzne (Encyklopedia PWN, 2019). Peruwiańczycy napływali zwłaszcza do miast nadmorskich, przy czym najbardziej pożądanymi lokalizacjami były Lima i Callao, w których liczba miejsc pracy i pensje były najwyższe. Ludzie opuszczali miejsca o surowszych warunkach bytowych i trudniejsze do utrzymania się w warunkach rozwijającej się gospodarki rynkowej, a także wysiedlane pod wielkie inwestycje, np. wydobycie ropy czy innych surowców. Liczba ludności w miastach rosła lawinowo, przez dwie dekady Lima z niewiele ponad 800-tysięcznego miasta stała się blisko trzymilionową metropolią, a w Callao liczba ludności się podwoiła. Jeszcze większy procentowo postęp wzrostu ludności odnotowano w mniejszych miastach: w okresie od 1940 do 1980 r. leżące przy granicy z Chile portowe miasto Tacna z 11 tys. mieszkańców rozrosło się do 100 tys., a leżący na północy port Chimbote może się pochwalić wzrostem liczby mieszkańców z 4 do 217 tys., czyli aż o 5325 proc. (INEI, 2019). Wzrost populacji miejskiej był i jest procesem trwałym, jednak mimo wzrostu ekonomicznego w miastach nie powstawały miejsca pracy dla osób wywodzących się z sektora rolniczego, a przemysł i struktura sektora produkcyjnego nadal pozostawały archaiczne i nie generowały nowych stanowisk pracy. Z danych INEI, czyli peruwiańskiego urzędu statystycznego wynika, że proporcje między ludnością wiejską i miejską na przestrzeni kilkudziesięciu dekad się odwróciły: w 1940 r. mieliśmy stosunek 65:35 proc. na korzyść wsi, natomiast w 1981 r. 35:65. Ostatnie pełne dane z 2012 r. pokazują jeszcze większą 
dysproporcję: 26:74 proc. W latach przeprowadzania spisów powszechnych dodano statystyki dotyczące ruchów migracyjnych ludności, gdzie w 1940 r. odsetek migrujących Peruwiańczyków wyniósł 9,5 proc. (czyli 588 tys. mieszkańców), w 1961 - 23 proc. (2,3 mln), a w 1972 r. 26 proc. (3,4 mln) (INEI, 2019).

W literaturze wskazuje się, że trudno wyodrębnić, jakie czynniki konkretnie wpłynęły po $1940 \mathrm{r}$. na decyzje jednostkowe o migracji, zazwyczaj podając ich katalog, w którym znajdziemy: ubóstwo, brak miejsc pracy na terenach wiejskich, niskie płace, zacofanie technologiczne i brak infrastruktury umożliwiającej usprawnienie procesów produkcyjnych na wsi, brak opieki zdrowotnej, niski poziom edukacji i nierówny podział ziemi (INEI 1987: 88). Co do tego ostatniego, to jeszcze w $1961 \mathrm{r}$. ponad połowa ziemi w Peru była uprawiana przez mniej niż 4 proc. właścicieli, a blisko 10 proc. ludności wiejskiej miało obowiązek yanaconaje, czyli darmowej pracy na rzecz właściciela ziemskiego, a uniknięcie tego obowiązku jest również wymieniane jako impuls do porzucenia terenów wiejskich na rzecz miast (INEI, 1987: 32). Zauważono też różne motywacje mieszkańców dzielnic peryferyjnych, dotyczące więzów formalnych z zajmowaną ziemią: największą presję odczuwali przybysze z daleka, z gór i dżungli, których wizja własnego domu na własnej działce była wizją dominującą, a zajmowany, najczęściej nielegalnie, teren był terenem docelowym. W budowie i zdobywaniu materiałów budowlanych pomagały solidarność i utrzymywanie więzów wewnątrz grupy pochodzącej z tych samych obszarów górskich czy leśnych. Z kolei mieszkańcy wybrzeża, przenoszący się do większych miast czy opuszczający lepiej sytuowane dzielnice, lżej traktowali obecne miejsce zamieszkania, nie wiążąc z nim planów i uważając je za tymczasowe, nawet jeśli spędzali tam kilkadziesiąt lat (INEI, 1987: 32-33). Migracji nie powstrzymały reforma rolna z $1961 \mathrm{r}$. ani kryzys, który zaczął się w Peru ok. 1975 r. i zmienił charakter przenosin ludności z trwałego na tymczasowy, w charakterze nomadycznego osiedlania się tam, gdzie są miejsca pracy, do czasu, aż koniunktura się nie zmieni.

Wciąż istotnym czynnikiem motywującym ludność do migracji jest aktywność grup partyzanckich, głównie Świetlistego Szlaku, znanego z krwawych zamachów terrorystycznych. Świetlisty Szlak (hiszp. Sendero Luminoso) to organizacja terrorystyczna i partyzancka zarazem, mająca za cel obalenie przemocą „burżuazyjnych” instytucji i zastąpienie ich „chłopskimi”, w ślad za chińskimi rozwiązaniami Nowej Demokracji. Jej działalność wyjątkowo zmotywowała ludność wiejską do wędrówki w kierunku miast i to $\mathrm{z}$ dwóch powodów. Pierwszy powód to terror, którego szczyt przypada na lata 1980-1992, w efekcie którego zginęło ponad 70 tys. Peruwiańczyków, a setki tysięcy musiało opuścić swoje siedziby. Drugi to kampania w końcowym okresie nasilenia walk, mająca na celu zajęcie miast, $\mathrm{z}$ Limą na czele. W ramach przygotowań do tych akcji ludność z terenów opanowanych przez Szlak była zachęcana do przenoszenia 
się w okolice ośrodków miejskich, w celu tworzenia zaplecza w momencie wybuchu walk w kolejnych miastach. Te de facto przesiedlenia wzorowane były na komunistycznych rozwiązaniach wietnamskich i chińskich z lat 60. i 70. XX w., więc często przeradzały się w exodus ludności obawiającej się o swoje życie (Bar, 1999: 201-205). „Wysoka skala przesiedleń z terenów górskich po 1980 r. dowodzi skali zagrożenia i braku poczucia bezpieczeństwa, jakie pojawiły się na terenach wiejskich wśród ludności cywilnej, stopnia rozbicia systemów ekonomicznych, mechanizmów pracy, do jakich musiało dochodzić z powodu wyludniania określonych osad i regionów, braku podstaw zapewniających przetrwanie i funkcjonowanie rodzin" (Śniadecka-Kolarska, 2016: 6).

Sytuacja polityczno-militarna zmieniła się po 1992 r., kiedy został aresztowany przywódca Szlaku Abimael Guzman. Wezwał on do zaprzestania terroru, rozejmu i oddania broni przez swoich dotychczasowych zwolenników. Jednak organizacja, ponosząc straty w swoich szeregach, dalej prowadziła działalność rewolucyjną, mimo niepowodzenia realizacji planu zdobycia większych miast. Walki nie ustały, ale zmniejszył się ich zasięg terytorialny, z czasem zmienił się również ich charakter. Już w latach 80. zdarzało się współpracować żołnierzom Szlaku z przemytnikami kokainy, nakładano na nich „podatek rewolucyjny” w celu finansowania działalności organizacji (Bar, 1999: 203). W latach 90. zapotrzebowanie na narkotyk wzrosło dramatycznie, głównie z powodu zaangażowania USA i władz w Bogocie w walkę z kolumbijskimi kartelami. Produkcja, handel i przemyt kokainy stały się intratnym sposobem dla Sendero Luminoso na przetrwanie kryzysu po fiasku powstania z 1992 r. Kierownictwo organizacji coraz bardziej angażowało się w działalność przestępczą, już bez wydźwięku ideologicznego, nie zmieniając swoich „rewolucyjnych” metod. Efekt dla ludności był podobny, a nawet sytuacja niektórych grup się pogorszyła, ponieważ mieszkańcy byli zmuszani do pracy niewolniczej na plantacjach (Bar, 199: 209). Szacowano, że już w 1992 r., czyli w chwili zatrzymania lidera i załamania się pewnej ciągłości walki zbrojnej, aż 80 proc. członków SL było zaangażowanych w obrót kokainą, aż 60 proc. masy kokainowej w Kolumbii pochodziło z Peru, a uprawy rośliny zajmują ok. 400 tys. hektarów i angażują co najmniej ćwierć miliona osób, pracujących w rolnictwie (Bar, 1999: 209). Na początku lat 90. zyski Świetlistego Szlaku z obrotu narkotykami szacowane były na $250 \mathrm{mln}$ USD rocznie (Strong, 1992: 13). Migracje przesiedleńcze lat 1980-2000 były procesem długotrwałym, zróżnicowanym, o zmiennej skali natężenia, obejmującym według szacunkowych danych od 600 tys. do $1 \mathrm{mln}$ obywateli, a wedle innych źródeł nawet $3 \mathrm{mln}$ osób. Trudności w ustaleniu liczebności tej fali migracji wynikają z faktu, że do 1992 r. nie prowadzono w Peru żadnych rejestrów dotyczących przesiedleń. Nawet po 1992 r. problemy migrantów nie były badane całościowo, a tylko w wybranych prowincjach. Fala przesiedleńcza 
tego okresu odcisnęła głębokie piętno na dzisiejszej rzeczywistości Peru. Około 380 osad i wspólnot zniknęło w tym czasie z mapy Peru, większość wskutek zniszczeń wojennych, ale część także wskutek opuszczeń" (M. Śniadecka-Kolarska, 2010: 5).

Migracje spowodowały w miastach powstawanie olbrzymich dzielnic peryferyjnych i pojawienie się ogromnego problemu społecznego, jakim są bezdomność i ubóstwo. Co dziesiąty Peruwiańczyk zamieszkuje osiedla marginalne (PWN, 2019). Inne istotne problemy, które wciąż są bolączką w Peru, to słaba opieka medyczna, dysfunkcyjny system edukacji oraz słabo rozwinięta infrastruktura transportowa, utrudniająca rozwój komunikacji zbiorowej i co za tym idzie, jeszcze bardziej obniżająca dostęp do opieki medycznej i edukacji (MMPV, 2019).

\section{Polityka mieszkaniowa w Peru}

Efektem migracji, zwłaszcza ich masowego i spontanicznego kształtu, był rozrost dzielnic biedy, w Peru nazywanych barriadas bądź pueblo joven, co w polskiej terminologii odpowiada pojęciom: osiedle peryferyjne czy dzielnica marginalna. Zjawisko dynamicznie i spontanicznie powstających dzielnic, określanych „zaimprowizowanymi osiedlami, powstającymi na obrzeżach miasta” (Kurowski, 2013: 39), jest znane w Peru od lat 50., a w połowie tej dekady Krajowe Biuro Planowania i Urbanistyki w Limie podaje opis barriady: osiedle powstałe na nielegalnie zajętym gruncie, formujące się bez planu, pozbawione podstawowych usług publicznych i społecznych, gdzie panują wyjątkowo niesprzyjające warunki bytowania. Zjawisko tak się rozprzestrzeniło, że już w 1961 r. parlament peruwiański uchwalił Ustawę 13517, dotyczą relacji państwo-osiedle peryferyjne (Kurowski, 2013: 40). Utrwaliło się, że do kategorii dzielnic marginalnych pasują określenia podkreślające braki, peryferyjność, nietrwałość i aspekt wizualny.

Dla przybyszów spoza aglomeracji lub większych miast barriadas czy peublo joven to praktycznie jedyna możliwość osiedlenia się i uniknięcia bezdomności. Mieszkańcy osiedli to osoby o niskich dochodach, ubogość usług publicznych nie sprzyja emancypacji z jednej strony, ale z drugiej strony osoby nowo przybyłe i osiedlające się w barriadas są szybciej akceptowane i szybciej się aklimatyzują.

W literaturze przedmiotu panuje przekonanie, że głównym czynnikiem wpływającym na sytuację lokalową, prócz migracji i rozpiętości dochodów, jest chroniczny brak dostępu do tanich mieszkań, nazywanych w Ameryce Łacińskiej vivienda popular (Kurowski, 2013: 45). W Peru, poczynając od zdobycia niepodległości w drugiej dekadzie XIX wieku po połowę lat 50. poprzedniego wieku, status społeczny był powiązany nie tylko z miejscem zamieszkania jako takim, ale głównie z odległością tego miejsca 
od ścisłego centrum, co najwyraźniej widać było w Limie. Rysował się także etniczny podział, najbardziej peryferyjne były dzielnice zamieszkane przez Indian i przybyszów z Afryki bądź ich potomków (Kurowski, 2013: 49). Po uzyskaniu niepodległości i pojawieniu się bardzo dobrej koniunktury gospodarczej, związanej m.in. z boomem zapotrzebowania na kauczuk, pojawiły się osiedla Chińczyków i Japończyków, a także emigrantów z Europy: Włochów, Anglików, Francuzów czy Niemców.

Jednak z biegiem czasu osadnictwo straciło etniczny charakter, a dzielnice peryferyjne, rozumiane jako miejsce osadnictwa ludzi biednych, zaczęły się pojawiać w Limie już w pierwszej połowie XX wieku (Kurowski, 2013:51). W tamtych czasach motorem napędowym powstawania tego typu osiedli była najczęściej chęć unikania płacenia czynszów i dzierżaw, a mieszkańcy barriadas od razu po zajęciu terenu żądali aktu sankcjonującego ich własność. Wskazując na ekonomiczne motywacje wewnątrzmiejskich migracji, część autorów wywodzi, że były one efektem dotarcia do Peru fali wielkiego kryzysu, co skutkowało m.in. paraliżem robót publicznych, obniżeniem płac bądź bezrobociem. W efekcie status materialny się obniżał z dnia na dzień do takiego stopnia, że rodziny nie było stać na utrzymanie wynajmowanego lokum (Meneses Rivas, 1974: 31).

Powstające spontanicznie osiedla peryferyjne, zasiedlane $\mathrm{w}$ ramach procesu zwanego „inwazją", stały się elementem nie tylko polityki, ale również narzędziem szybkiego wzbogacania się ich właścicieli. Inwazje na tereny publiczne, już w latach 30., często były inspirowane przez władze bądź odbywały się za ich daleko idącym przyzwoleniem, co powodowało, że taka metoda poszukiwania nieruchomości stała się coraz bardziej popularna wśród nie tylko ich nabywców, ale także zbywców. Niektóre tereny prywatne na obrzeżach miast, mało atrakcyjne mieszkaniowo, inwestycyjne czy rekreacyjne, były zamienianie w barriadas za wiedzą i namową dotychczasowego właściciela czy jego administratorów. Władze przyznawały nowym mieszkańcom tytuł prawny, właścicielowi odszkodowanie.

Przełomowym wydarzeniem, jeśli chodzi o skalę peryferyjnego, spontanicznego mieszkalnictwa, było trzęsienie ziemi w 1940 r. w Limie i okolicach (Kurowski, 2013: 53). Na skutek katastrofy część zabudowy mieszkaniowej została zniszczona, a kolejna część przetrwała, ale była w stanie nadającym się tylko do wyburzenia bądź do gruntownego remontu. Skala zniszczeń i opieszałość odbudowy były jednak tak duże, że lokatorzy opuszczający swoje domostwa mieli uzasadnione obawy, iż więcej do nich nie wrócą. W tym czasie w Limie powstało sześć osiedli peryferyjnych, a w sąsiednim Callao 11 kolejnych. Mieszkańcy, którzy opuścili swoje mieszkania z powodu trzęsienia ziemi, w powstałych po nim barriadas żyli do lat 70. bądź 80 . Nowym czynnikiem było to, że marginalne osiedla powstały często w dawnych centralnych dzielnicach. Zamieszkali w nich mieszkańcy do czasów katastrofy radzili 
sobie na rynku pracy, ale brak lokali mieszkalnych zmusił ich do zamieszkania w barriadas i jednocześnie zdjął z nich odium wstydu, zniwelował piętnowanie ich jako biedoty i ludzi niezaradnych życiowo (Meneses Rivas, 1974: 32). Masowość budowy wielu osiedli w jednym czasie wywołała też kolejny problem: bardzo duże trudności w planowaniu przestrzennym. Osiedla peryferyjne zaczęły wpływać na kierunki rozwoju urbanistycznego, a nie podążać za nimi jak do tej pory. Powstanie 17 osiedli po trzęsieniu ziemi w $1940 \mathrm{r}$. wywołało spontaniczne zbliżenie się terytorialne Limy i sąsiadującego portu Callao, ponieważ w dużym stopniu nowe dzielnice pojawiały się pomiędzy tymi dwoma miastami, inicjując połączenie się obu ośrodków miejskich w aglomerację (Kurowski, 2013: 54).

Na przykładzie Limy widać, jak sytuacja mieszkaniowa w połowie XX wieku zaczyna wymykać się spod kontroli: w latach 1951-1956 do stolicy przybyło 161 tys. nowych mieszkańców, a między 1956 a 1961 r. kolejne 265 tys. (Kurowski, 2013: 59). Dodatkowo stan ten komplikowało przejście sytuacji społecznej i demograficznej w tzw. fazę wczesnej transformacji, kiedy spada współczynnik zgonów w społeczności i równie szybko rośnie współczynnik urodzeń (Węcławowicz, 2007: 35). Deficyt mieszkaniowy w 1957 r. obliczono na ponad 130 tys. lokali, w znaczeniu mieszkań będących rynkowym towarem, w którego posiadanie wchodzi się drogą transakcji kupna-sprzedaży, za gotówkę czy na kredyt. Równocześnie narodziło się zjawisko wewnętrznych migracji miejskich, kiedy mieszkańcy rezygnują z najmu i przenoszą się do dzielnic peryferyjnych (Kurowski, 2013: 58). Połowa XX wieku to czas, kiedy miasta peruwiańskie zaczęły tracić odziedziczoną po czasach kolonialnych formę koncentryczną, gdzie zabudowa gromadziła się w kolejnych kręgach, oddalających się od centrum, a przekształcały się w miasta spolaryzowane, w których zabudowa ruszała w różnych nieplanowych miejscach, często bez kontroli i infrastruktury.

Władze peruwiańskie najszybciej na kontynencie doceniły wagę problemu i już w 1961 r. podjęły pierwszą próbę uregulowania sytuacji własnościowej na gruntach miejskich i podmiejskich, uchwalając Ustawę o dzielnicach marginalnych. Jednak ani ta ustawa, ani kolejne regulacje nie ustabilizowały sytuacji, a polityka mieszkaniowa względem osób o niskich dochodach przez całą dekadę nie uległa poprawie, co pod koniec dziesięciolecia doprowadzało do wielodniowych zamieszek i konfrontacji z siłami porządkowymi (Kurowski, 2013: 62).

Mimo zwrócenia uwagi na problematykę paraliżu oficjalnej polityki mieszkaniowej i prób najpierw jej regulacji, a później wsparcia, kwestia posiadania mieszkania czy domu zależała przede wszystkim od prywatnej inicjatywy mieszkańców, zwłaszcza po pogorszeniu się koniunktury gospodarczej w połowie lat 70. Peruwiański badacz Manuel Braga wyliczył, że przeciętnie rodzinie budowa domu zajmuje 25 lat, licząc od objęcia w posiadanie gruntu i zakładając, że odkłada 15 proc. dochodu na cele 
budowy. Dodał, że rodzina podczas budowy mieszka w tym domu, a po latach tego typu procesów urbanizacyjnych, w 1987 r. tylko połowa domów budowanych w dzielnicach marginalnych miała prąd i dostęp do bieżącej wody i kanalizacji. Zdobycie schronienia nie rozwiązuje problemu biedy, ale nawet pogarsza dostęp dzieci do edukacji i ogółu do usług medycznych, choćby ze względu na lokalizację. Poza tym, ukończone tak dużym prywatnym wysiłkiem domy są względnie droższe niż budowane innym systemem, odgrywają one rolę domów wielorodzinnych, mimo że zgodnie z planem były przeznaczone dla jednej rodziny, i nie rozwiązują problemu lokalowego kolejnych pokoleń (Kurowski, 2013: 64).

Od drugiej połowy lat 70. widać zmianę nastawienia władz peruwiańskich do zjawisk urbanizacji, zarówno tej formalnej, jak i „pozaformalnej”, co oznacza wszelkie spontaniczne formy osiedlania się w miastach bądź na ich obrzeżach. Do tej pory państwo ograniczało się do roli obserwatora i arbitra, a jego aktywność sprowadzała się do cichego wskazywania terenów do zasiedlenia i akceptowania powstawania osiedli marginalnych. Jednak praktyka ograniczała się do liberalnej wizji polityki mieszkaniowej, czyli wsparcia prywatnej inicjatywy na tym odcinku. Powstały w $1960 \mathrm{r}$. Narodowy Instytut Mieszkaniowy, mając za oręż wspomnianą Ustawę z 1961 r., przyjął na siebie rolę czynnika odpowiedzialnego za infrastrukturę miejską i pozostałe aspekty urbanizacji, jednak nie inicjował szerzej zakrojonych programów mieszkaniowych, a jedynie dyskusje na temat ich przyszłej formy. Próbowano wprowadzać programy kredytów hipotecznych bądź subsydiów dla deweloperów, a beneficjentami obu tych form wsparcia mieli być docelowo ludzie o niskich dochodach. Jednak programy te miały po pierwsze ograniczony zasięg, po drugie trafiały głównie do klasy średniej. Po kilku latach zostały zarzucone (Kurowski, 2013: 64).

Lata 80. i 90. nie przyniosły głębokich zmian w polityce mieszkaniowej: nadal preferowano wspieranie budownictwa prywatnego i różne formy legalizacji dzielnic peryferyjnych, choć przeprowadzono eksperyment z przeniesieniem ciężaru stymulacji polityki mieszkaniowej na samorządy, stosunkowo szybko zarzucony. Bierność państwa spowodowała, że wycofano się nawet ze wsparcia programów rozwojowych mieszkalnictwa, a władze ograniczyły się do ogólnonarodowych amnestii dla uczestników inwazji, poprzedzających budowę barriadas (1993 r. i 1996 r.).

Przełomowy dla polityki mieszkaniowej w Peru okazał się XXI wiek. Od 2001 roku organy państwowe rozpoczęły dywersyfikację programów pomocowych, stawiając na rozwiązania wielosektorowe, obejmujące: banki, państwo, deweloperów, inwestorów zagranicznych i beneficjentów. Nastąpiła również integracja polityki, powołano przeznaczony mieszkalnictwu resort i uchwalono Narodowy Plan Mieszkaniowy. Celem nowej polityki nie miało być budowanie mieszkań ani finansowanie ich budowy, tylko kojarzenie grup o zbieżnych interesach, czyli deweloperów, potrzebujących 
i instytucji finansowych. Wprowadzono też programy mające podnieść standard już zasiedlonych osiedli, budując m.in. boiska i infrastrukturę sportową w miejscach ich do tej pory pozbawionych. Mimo wielu prognostyków zmian w dobrym kierunku krytycy wskazywali, że pomoc i tak nie trafia do planowych beneficjentów z powodu wadliwych kanałów dystrybucji ofert, korupcji i nieefektywności administracji publicznej. Próbowano ponownie przesunąć kompetencje mieszkaniowe w gestię samorządów i uregulować sytuację osiedli marginalnych, legalizując je w pełni i nadając mieszkańcom tytuł własności. Jednak równocześnie państwo zmieniło swój stosunek do powstawania nowych barriadas, starało się do tego nie dopuszczać, stosując pełen wachlarz metod konfrontacyjnych, z użyciem sił porządkowych włącznie. Uchwalony na lata 2007-2015 Narodowy Plan Mieszkaniowy, w którym rola państwa została jasno określona jako „promotora problematyki mieszkaniowej i organizatora ułatwiającego inwestycje podmiotom prywatnym, którym przyznano funkcję wykonawcy polityki mieszkaniowej”, pokazuje, że peruwiańska polityka mieszkaniowa jest nie tylko pasywna, ale też daje mieszkańcom szeroki margines inicjatywy i dopuszcza wiele elastycznych form finansowania inwestycji.

\section{W poszukiwaniu efektywnego modelu pomocy rozwojowej}

Przełom wieków XX i XXI to okres, kiedy debata nad efektywnym modelem pomocy rozwojowej zaczęła rozgrzewać ekspertów. Publikacją, która odbiła się szerokim echem, była książka Karawana kryzysu. Za kulisami przemysłu pomocy humanitarnej, która ukazała się w języku polskim w 2011 r., napisana przez Holenderkę, wieloletnią pracownicę agencji pomocowych, Lindę Polman. W publikacji tej autorka miażdżąco krytykuje organizacje zajmujące się pomocą za stosowane metody oraz społeczne i infrastrukturalne efekty ich działań. Ukazuje patologie popularnych dróg pomocy, która ma u swoich źródeł szczytne cele. Wskazuje, że niesienie pomocy stało się przemysłem, w którym obraca się miliardami, a walcząc o jak największy udział w rynku robi się wszystko, aby wyprzedzić konkurentów, często nie zastanawiając się nad długofalowymi skutkami działań.

Wcześniej rozpoczęła się krytyka z pozycji endogeniczności rozwoju. Ekonomistka Dambisa Moyo, wieloletnia pracowniczka banku inwestycyjnego Goldman Sachs, w swojej książce Dead Aid z 2009 r. tłumaczy, jak pomoc z zewnątrz może wpłynąć destrukcyjnie na lokalne wspólnoty, demotywując do kontynuowania dotychczasowej aktywności, czy to społecznej, czy biznesowej, zniechęcając do poszukiwania własnych rozwiązań i tłamsząc jakiekolwiek przejawy przedsiębiorczości. Nawiązując 
do twierdzeń Williama Easterly, autorka uważa, że intensywna pomoc z zagranicy, świadczona przede wszystkim przez organizacje trzeciego sektora, dosłownie korumpuje lokalne władze i tworzy „pomocowe” lobby, żerujące jak pasożyt na strumieniach materialnych i finansowych środków. Ostatecznie konstatuje ona, że en masse pomoc rozwojowa klasycznie pojmowana czyni więcej zła niż dobra. Pisze: „Czy dla całego kontynentu jest to rozsądne i praktyczne, aby jego przyszłość zależała od napływu pomocy i politycznych strategii, które są definiowane przez organizacje pozarządowe lub pomoc zagraniczną? Przypuszczam, że nie. Chciałabym jeszcze dotknąć sprawy fundamentalnej - otóż tego rodzaju pomoc oznacza zgodę na zaangażowanie bez końca. Afrykańskie rządy nie widzą kresu pomocy, żaden z nich nie mówi niczego w rodzaju: właściwie, za 30 lat, nie będziemy już otrzymywać żadnej pomocy, więc powinniśmy zacząć planować” (Moyo, 2009: 4).

Dambisa Moyo, pochodząca z Zambii, zauważa także, że „wysokie sumy pieniędzy przeznaczanych na pomoc dla Afryki są w najlepszym wypadku wykorzystywane w sposób zupełnie bezproduktywny" (Moyo, 2009: 32). I przytacza jako najbardziej jaskrawy przykład prezydenta jednego z najbiedniejszych państw na świecie, Republiki Środkowoafrykańskiej, urzędującego na tronie ze złota. Zauważa ona, że „w dyskusji na temat rozwoju jest wiele publikacji mówiących o tym, że w państwach, w których nie ma w ogóle prywatnego sektora w gospodarce albo w których jest on bardzo słaby, rząd po prostu pozostaje jedyną instytucją, która dysponuje jakąkolwiek gotówką. I tak trwa błędne koło" (Moyo 2009: 39).

Hernando de Soto, peruwiański ekonomista, w latach 90. XX wieku stwierdził, że rozwiązaniem problemu dzielnic nędzy jest przekazanie osadnikom zajmowanej ziemi na własność. Nieistotne przy tym dla H. de Soto było, czy do tej pory właścicielem tej ziemi było państwo, czy osoby prywatne (tym należało wypłacić rekompensaty $\mathrm{z}$ budżetu centralnego). Celem takiego rozwiązania nie było tylko uregulowanie problemu własności czy wyzwolenie się z biedy poprzez uwłaszczenie, ale przede wszystkim stworzenie możliwości zdobycia kapitału poprzez obciążenie świeżo zdobytej hipoteki. To pozwalałoby na inwestycje i dalszą akumulację kapitału, co dla niezamożnych mieszkańców krajów rozwijających się jest najlepszą szansą, a czasem nawet jedyną drogą finansowego awansu (de Soto, 2002: 86-89). De Soto uważał, że w odniesieniu zarówno do ziemi i innych nieruchomości, jak i do przedsiębiorstw, człowiek najlepiej nimi zarządza wtedy, gdy ma do nich legalny i jasny tytuł własności, którego nikt nie kwestionuje. Stąd dla rozwoju gospodarczego państw, w tym rozwijających się takich jak Peru, bardzo istotne jest, aby własność i solidne tytuły do tej własności ściśle określające jej zakres i granice, były jak najbardziej rozpowszechnione.

To właśnie system obrotu własnością i jej tytułami jest według de Soto podstawą uruchamiania zamrożonego w tej własności kapitału. Urzędowe tytuły własności 
mogą bowiem posłużyć jako wiarygodny zastaw pożyczek i kredytów na cel inwestycji i rozwoju przedsiębiorstw. W krajach rozwijających się można by w ten sposób uruchomić kapitał dla rozwoju (de Soto, 2002: 96). Krytycy takiego rozwiązania kwestii własności i powiązanego z nim systemu finansów opartego na tytułach własności, wskazywali na przesadny idealizm, a niektórzy wręcz na naiwność takiego rozwiązania. Argumentowali, że mieszkańcy dzielnic nędzy to ludzie niewystarczająco zaznajomieni ze światem prawa i finansów, część z nich to analfabeci. Uważali oni, iż istnieje realne zagrożenie, że właściciele, obciążając hipotekę, bezproduktywnie skonsumują uzyskane środki albo będą podejmowali zbyt ryzykowne decyzje biznesowe i padną ofiarą spekulacji czy oszustwa (Deininger, 2003: 99).

Dwóch znanych badaczy pomocy rozwojowej, Abhijit Banerjee z Indii i amerykańsko-francuska ekonomistka Esther Duflo, w swoich pracach postulują ścisłą kooperację strony udzielającej pomoc $\mathrm{z}$ administracją na poziomie lokalnym i kierunkowanie pomocy bezpośrednio do wspólnot potrzebujących - tam, gdzie realnie są problemy, z pominięciem szczebla państwowego. Autorzy przekonują, że słabe działania instytucji państwowych w krajach rozwijających się wynikają często ze słabości organizacyjnej administracji publicznej, a nie tylko z braków finansowych. Jako przykład Banerjee i Duflo podają podstawowy problem szkolnictwa w Indiach, którym jest absencja nauczycieli związana z małą efektywnością systemu kontroli ich obecności (Banerjee, Duflo, 2011: 7-8). Przekonują, że sam strumień pieniędzy czy darmowej pomocy, np. żywnościowej, nie pomaga osiągnąć wyznaczonych celów, a często efekty są zaskakujące, np. im więcej ryżu wysyła się w ramach pomocy humanitarnej, tym bardziej spada jego spożycie. Zaangażowanie pracowników wspieranych sektorów i beneficjentów ich pracy, czyli, idąc za powyższym przykładem, nauczycieli i ich uczniów, jest kluczowe nie tylko dla właściwej percepcji pomocy, ale też dla jej skutecznego udzielania. A poza tym mechanizm współpartycypacji, zarówno beneficjentów, jak i pracowników dysfunkcyjnego systemu opieki, nie wymaga wiele, czasami są to proste gesty budujące więzi, w przypadku hinduskich nauczycieli problem zażegnano w dużym stopniu, fotografując codziennie całą klasę razem z nauczycielem na początek zajęć i po ich zakończeniu.

\section{Korzenie Fundacji Coprodeli i jej schemat organizacyjny}

Sytuacja społeczna w Peru była impulsem do założenia fundacji zajmującej się pomocą rozwojową. Korzenie Fundacji Coprodeli sięgają 1983 r., kiedy jej założyciel, ojciec Miguel Ranera, jezuicki misjonarz, rozpoczął swój pobyt w stolicy Peru, Limie. Wykonując czynności wchodzące w zakres posługi kapłańskiej, nabywał coraz więcej 
wiedzy na temat codziennych problemów społeczności, na rzecz której pracował, ogromu biedy i nikłych perspektyw zmiany tego na lepsze. Aby wyrwać lokalne społeczności $z$ letargu, postanowił nadać impuls z zewnątrz i założyć fundację walczącą $z$ ekstremalnym ubóstwem i wykluczeniem społecznym. To miała być odpowiedź z jednej strony na dysfunkcję i braki polityki społecznej, w tym mieszkaniowej, państwa peruwiańskiego, a z drugiej na niedostosowaną do lokalnych realiów pomoc prowadzoną przez organizacje humanitarne oraz charytatywne. W $1989 \mathbf{r}$. w Madrycie powstała Fundacion Coprodeli, która postawiła sobie za cel wspieranie rozwoju społecznego w Peru, jednak nie wg modelu interwencji z zewnątrz, w czym gustowały zagraniczne organizacje pomocowe, ale zapobiegania i zrównoważonego rozwoju. Jak można przeczytać w raportach z działalności fundacji: „Peru - według Miguela Ranery - przypominało wówczas »kraj afrykański«, było bowiem dotknięte skrajną biedą, chorobami i dezorganizacją społeczną. Szczególnie złe warunki panowały na przedmieściach Limy - w Callao, dlatego właśnie tutaj Miguel Ranera rozpoczął swoją misję, osiadając w parafii św. Róży. Pierwsze działania, którym przyświecała ideologia chrześcijańska, koncentrowały się na prowadzeniu jadłodajni i dostarczaniu podstawowych produktów najbiedniejszym rodzinom. Jak podkreślono w raportach z działalności fundacji, „byli to biedni mieszkańcy, którzy pomagali innym biednym mieszkańcom" (Kochanowska, 2013: 77).

Stając w obliczu ekstremalnego ubóstwa, o. Miguel kładzie nacisk na edukację, przedsiębiorczość i ochronę młodych jako środki wzmocnienia zmarginalizowanych wspólnot (Coprodeli USA, 2019). „Główną strategią fundacji jest »edukacja i przedsiębiorczość jako wehikuły rozwoju«, a w wizji organizacji jest podkreślone, że beneficjenci fundacji są »wzmacniani«, aby sami stać się później agentami zmiany wewnątrz swoich społeczności, a programy promują długoterminowy i trwały rozwój” (Coprodeli USA, 2019).

Pierwszym celem działalności fundacji było propagowanie edukacji powszechnej, co poskutkowało założeniem w 1993 r. szkoły San Agustin de Hipona w portowym mieście Callao, leżącym na przedmieściach stolicy. W następnych latach powstała zarządzana przez fundację sieć, składająca się z trzech szkół, kliniki i centrum umiejętności, która koncentrowała się na dzieciach pochodzących z grup wysokiego zagrożenia wykluczeniem społecznym (Coprodeli USA, 2019). Aby wzmocnić działalność fundacji i zakres realizacji jej celów, w 1999 r. założony został amerykański oddział Coprodeli w USA z dwiema siedzibami: w Waszyngtonie i Chicago. Struktura amerykańskiej organizacji różni się tym, że jest zarządzana przez radę 17 dyrektorów, odgrywających rolę zarządu i pracujących na zasadzie wolontariatu. Amerykańskie biura łączyły rolę organizatorów akcji fundraisingowych i koordynatorów programów prowadzonych przez fundację. Fundatorzy Coprodeli USA są zorganizowani w „sieć 
wsparcia”, która gromadzi zarówno osoby prywatne, jak i organizacje czy spółki. Wsparcie może polegać na: wpłatach, wzięciu udziału w programach opieki, w których finansuje się jedno dziecko lub wspiera materialnie inną drogą, oraz pomocy organizacyjnej czy realizacyjnej na miejscu w Peru. Coprodeli USA oferuje wzięcie udziału w „projekcie sponsorowanym”, za pomocą którego można sfinansować wyposażenie klasy albo budowę centrum socjalnego, bądź w „partnerstwie strategicznym”, w którym współpraca trwa dłużej i obejmuje bardziej holistyczne projekty, w ramach których podmioty wymieniają się również know-how i wspomagają nawzajem zasobami ludzkimi, nie tylko finansowo. Może to być wieloletni program dokarmiania uczniów, jak i trwałego dostarczania przyborów szkolnych (Coprodeli USA, 2019).

Od 2001 r. działalność fundacji w Peru rozszerzyła się i rozpoczęto realizacje programów pomocowych w drugiej lokalizacji na przedmieściach - Pachacutec. Uruchamiano kolejne lokalizacje $\mathrm{w}$ regionach położonych na południe od Limy: Chincha, Canete, Ica i Pisco oraz w San Martin, leżącym na północ od stolicy. W 2013 r. rozpoczęła się interwencja w dolinie Huallaga w amazońskiej dżungli. Planuje się budowę około 400 domów rocznie, a beneficjentami będzie 12 biednych społeczności Amazonii (Coprodeli USA, 2019).

Podział strukturalny organizacji i schemat działania jest stosunkowo prosty i przejrzysty. Kluczowa w układzie jest centrala fundacji z siedzibą w Madrycie i jej oddział w Andaluzji. Zatrudnione w nich na stałe są tylko dwie osoby, za to jako wolontariusze pracuje w obu miejscach ponad 400 osób. To z Hiszpanii są koordynowane największe projekty i programy, tam też odbywa się planowanie i budżetowanie. Północnoamerykańska gałąź fundacji, Coprodeli USA, jest wspierana przez 35 wolontariuszy, którzy zajmują się zbieraniem funduszy, częściowo też rekrutacją i koordynacją poszczególnych projektów. A największa jest peruwiańska część organizacji, w której zatrudnionych jest 800 pracowników, z czego połowa - głównie nauczyciele - jest opłacana z centralnego budżetu państwa peruwiańskiego. Wspierani są przez ćwierć tysiąca wolontariuszy, głównie Peruwiańczyków, ale też Hiszpanów, Amerykanów, Basków, a także Polaków. Pracownicy Coprodeli w Peru to zarówno personel szkół i centrów, jak i ekipy budowlane, stawiające obiekty. Reasumując, w prace Fundacion Coprodeli na trzech kontynentach jest zaangażowanych ok. 1500 osób, z tego blisko połowa to pracujący na zasadach wolontariatu (Coprodeli USA, 2019).

\section{Model działania stosowany przez Fundację Coprodeli}

Działania Fundacji Coprodeli są zgodne z jednym z elementów prezentowanej wyżej teorii Abhijita Banerjee i Esthera Duflo, wedle której udzielana pomoc działa 
tylko wtedy, kiedy wymusza zaangażowanie zarówno mieszkańców, jak i miejscowych władz. Model zaproponowany przez Coprodeli należy ocenić jako o wiele bezpieczniejszy dla uczestników niż oparty na ideach de Soto. Fundacja Coprodeli walkę z wykluczeniem społecznym zaczyna od budowy obiektów mieszkalnych, stosując zasadę partycypacji zarówno w zakresie kapitału (środki pochodzą od fundacji Coprodeli, przyszłych mieszkańców, władz i wspólnot lokalnych, biznesu, państwa), jak i pracy (często, zwłaszcza na początku, ze strony mieszkańców jest to praca ich samych). Inicjatywa zaczyna się w określonym miejscu i czasie, z czasem kolejne rodziny nabierają zaufania do akcji fundacji i włączają się w proces rozwoju osiedla, a budowa nabiera rozmachu. Automatycznie włącza się tu także mechanizm kontroli. Z czasem dołączają kolejni uczestnicy: struktury władzy, lokalny biznes, kolejne organizacje pozarządowe (subsydiarne bądź komplementarne względem Coprodeli). Po zaspokojeniu podstawowej potrzeby, czyli dachu nad głową, w dalszym rzędzie pojawiają się: przychodnia, szkoła, świetlica, ośrodek rozwoju kompetencji i przedsiębiorczości, a także dalsze elementy infrastrukturalne: drogi, chodniki, oświetlenie, irygacja, boiska, korty, basen itp. Działacze Fundacion Coprodeli postawili na budowę relacji międzyludzkich, wzrost zaufania między mieszkańcami i administracją lokalną, rządową, przedstawicielami biznesu i organizacji pozarządowych, stwarzając warunki do powstania i rozwoju wspólnot lokalnych. Zaspokojenie podstawowych potrzeb, $\mathrm{w}$ tym zapewnienie elementarnego bezpieczeństwa, ma w wizji kierownictwa fundacji zapewnić fundamenty do dalszej aktywności, czy to edukacyjnej, czy biznesowej, w formie przedsiębiorczości bądź inwestycji, ma być impulsem do dalszego rozwoju.

Modelowym przykładem działalności Coprodeli jest inwestycja w Ica, mieście liczącym niewiele ponad 150 tys. mieszkańców, leżącym na pustyni, choć w regionie turystycznym. W administracyjnych granicach miasta znajduje się Huacachina, jedyna oaza w Ameryce Południowej, globalnej rangi ośrodek sandboardingu, a w promieniu kilkudziesięciu kilometrów leży płaskowyż Nazca oraz miasto Pisco, od którego nazwano gatunek alkoholu, rozpoznawalny globalnie, a także wybrzeże oceaniczne.

Fundacja działa na przedmieściach miasta, nazywanych Subtanjalla, doświadczonego przez trzęsienie ziemi w 2007 r., które w całym regionie zniszczyło nieodwracalnie 77 proc. domów, pozostawiając 80 tys. rodzin bezdomnymi. W Subtanjalla mieszka 17 tys. osób, bezrobocie dotyka 19 proc. populacji, poniżej granicy ubóstwa egzystuje 72 proc. mieszkańców. Dla większości tamtejszych rodzin górny pułap zarobków to 60 USD miesięcznie.

Mimo dużego potencjału turystycznego region uznawany jest za trwale zagrożony ubóstwem, jest nawiedzany przez trzęsienia ziemi, ale jest celem migracji ludności z terenów położonych dalej od oceanu. Przybywająca ludność poszukuje zatrudnienia w rolnictwie, jednak terenów nadających się pod uprawę jest niewiele, mimo że 
produkty z regionu znajdują coraz więcej nabywców. System edukacji się załamał z powodu fizycznego zniszczenia infrastruktury. Mimo tego, że Ica jest miastem stosunkowo rozwiniętym, będącym siedzibą wielu spółek o krajowej renomie, to lokalne władze nie są $\mathrm{w}$ stanie zapewnić usług komunalnych rosnącym przedmieściom, w tym Subtanjalli (INEI, 2019; Coprodeli, USA 2019).

Proces odbudowy fundacja rozpoczęła w 2009 r., dwa lata po trzęsieniu ziemi. Pierwszą inwestycją była szkoła, jednak przez pierwszy rok dzieci uczyły się w miejscowej kaplicy, korzystając z prowizorycznych mebli i pomocy naukowych. Otwarcie nowo postawionej szkoły było punktem zwrotnym w życiu osiedla, od tego czasu w ramach inwestycji mieszkańcy mają do dyspozycji:

- szkołę dla 650 uczniów,

- centrum zdrowia, przyjmujące 30 tys. pacjentów rocznie,

- świetlicę dla dzieci, w której mogą spędzać czas przed lekcjami i po nich,

- punkt pomocy humanitarnej,

- 800 domów,

- system nawadniania terenu ze studni głębinowej,

- instalację elektryczną, bieżącą wodę oraz kanalizację,

- mikropark przemysłowo-technologiczny, mający docelowo wygenerować 300 miejsc pracy.

Coprodeli od początku działalności w Peru prowadziła 25 szkół, do których uczęszczało 65 tys. dzieci. W placówkach dzieci dostają również posiłki, mają lekcje angielskiego, informatyki oraz kursy z praw obywatelskich i przygotowania do biznesu, mają również dostęp do biblioteki. Szkoły prowadzone przez fundację regularnie plasują się w czołówkach rankingów, wspomniana pierwsza szkoła założona przez fundację, Agustin de Hipona, zdobyła piątą pozycję w rankingu szkół w Peru (INEI, 2019).

Oprócz szkół i towarzyszącym im centrów doskonałości, gdzie dzieci mogą uzupełniać wykształcenie bądź przygotować się do wejścia w życie zawodowe, Coprodeli prowadzi siedem niezależnych centrów o podobnym profilu, do których trafiają dzieci wyjątkowo narażone na wykluczenie. Opuszczające je dzieci są obejmowane trwającym jeszcze kilka lat programem opiekuńczym, obecnie ma on 700 nastoletnich uczestników. W centrach są prowadzone kursy zawodowe, zbliżone działaniem do polskich centrów kształcenia ustawicznego czy szkół policealnych, które ukończyło 17 tys. słuchaczy (Coprodeli USA, 2019).

Kiedy Fundacja Coprodeli przeszła od budowy pojedynczych szkół do rozwijania całych centrów urbanizacji (obejmujących centrum usług socjalnych składających się ze szkoły, kliniki medycznej oraz ośrodka dla młodzieży) (Coprodeli USA, 2019) i planowała budować kompletne osiedla mieszkaniowe, rząd włączył 
lokalizacje prowadzone przez fundacje do programów wsparcia mieszkaniowego. $\mathrm{Na}$ rzecz fundacji można było skorzystać $\mathrm{z}$ systemu tzw. bonów mieszkaniowych przekazywanych przez władze państwowe, m.in. młodym małżeństwom oraz słabiej sytuowanym jednostkom i rodzinom. Stało się to pośrednim współfinansowaniem budowy i porządkowania osiedli w ramach akcji Coprodeli, wzmocniało poczucie wspólnoty lokalnej oraz ograniczyło koszty działania organizacji. Władze lokalne także podejmowały inicjatywy polegające na obniżaniu podatków do minimum bądź zwalniały fundację $\mathrm{z}$ nich całkowicie. Finansowanie dodatkowo wspierane było przez międzynarodowe organizacje pozarządowe i lokalny biznes oraz wspomnianych pracowników w dużej liczbie zatrudnionych na zasadzie wolontariatu, co wszystko razem obniżało koszty do minimum.

W efekcie działań Coprodeli zbudowano ponad 3,5 tys. domów w technologii antysejsmicznej. Fundacja wspiera również rodziny i lokalne wspólnoty w przejściu przez zawiłe procedury prawne, dotyczące legalizacji statusu zajmowanych nieruchomości, do dzisiaj z tej formy wsparcia skorzystało ok. 10 tys. Peruwiańczyków (Coprodeli USA, 2019).

$* * *$

Mimo poprawiającej się sytuacji gospodarczej Peru nadal boryka się z wieloma problemami, dotyczącymi skrajnej biedy i zagrożeń z tego wynikających: złych warunków mieszkalnych, sanitarnych, małych szans edukacyjnych i ochrony zdrowia. Wiele organizacji pozarządowych, w tym międzynarodowych, działa pod Andami oraz stara się wyręczać i wspierać rząd w Limie w polityce społecznej i rozwoju. Coprodeli stosuje swoją własną strategię, łączy z jednej strony środowiska i ludzi ponad granicami państw, a z drugiej ludzi, środowiska i władze lokalne. Angażuje dużą liczbę wolontariuszy, lokalne społeczności i władze. Promuje wymianę doświadczeń i wiedzy między różnymi częściami organizacji i ludźmi zaangażowanymi w różne projekty. Opiera swoją działalność na współpracy i życzliwości, na myśleniu o rozwoju społeczno-gospodarczym poprzez słowa „razem” i „oddolnie”. W efekcie ważne i namacalne korzyści z działalności tej organizacji odnosi rocznie w Peru przeszło 375 tys. dzieci, młodzieży i dorosłych (Coprodeli, 2017), a procesy uruchamiane przez to wsparcie przynoszą ważne skutki dla rozwoju społeczno-gospodarczego. Interkontynentalny model działania odnosi zamierzone skutki, a rozmieszczenie: centrala w Europie, zaplecze finansowo-organizacyjne w Ameryce Północnej i główny obszar realizacji programów, projektów i interwencji w ramach pomocy rozwojowej w Ameryce Południowej pozwala uzyskać efekt synergii, unikając ograniczeń, z którymi borykają się zarówno organizacje globalne, działające na masową skalę, jak i organizacje lokalne, które wiążą bariery lokalne. 


\section{Bibliografia}

Amsden, A.H. (2007). Escape from Empire. The Developing World's Journey through Heaven and Hell. Boston: MIT Press.

Arczewska, M. (2011). Wspótpraca administracji publicznej i organizacji pozarządowych w tworzeniu polityk publicznych dotyczacych spraw społecznych i ochrony środowiska. Warszawa: Instytut Spraw Publicznych.

Banerjee, A., Duflo, E. (2011). More than 1 Bilion People Are Hungry in the World. But what if experts are wrong?. Foreign Policy, 5-6.

Banerjee, A., Duflo, E. (2014). Poor Economics. A Radical Rethinking of the Way to Fight Global Poverty. New York: Public Affairs.

Banerjee, A., Duflo, E. (2009). The Expiremental Approach to Development Economy. The Annual Review of Economics, 1.

Bar, W. (1999). Na krwawym szlaku. Lublin: Wyd. KUL.

Bassett, T.J., Winter-Nelson, A. (2010). The Atlas of World Hunger. Chicago: University of Chicago Press.

Biuro Analiz Sejmowych (2017). Polityka rozwojowa i humanitarna Unii Europejskiej. Warszawa: Wydawnictwo Sejmowe.

Collier, P. (2007). The Bottom Billion: Why the Poorest Countries are Failing and What Can Be Done About It. Oxford: Oxford University Press.

Davis, M. (2009). Planeta slumsów, tłum. K. Bielińska. Warszawa: Książka i Prasa.

Deininger, K. (2003). Land Policies for Growth and Poverty Reduction. Washington: World Bank and Oxford University Press.

Domosławski, A. (2007). Gorączka latynoamerykańska. Warszawa: Świat Książki.

Domosławski, A. (2013). Śmierć w Amazonii. Nowe Eldorado i jego ofiary. Warszawa: Wielka Litera.

de Soto, H. (1991). Inny szlak: niewidzialna rewolucja w Trzecim Świecie, tłum. S. Makowiecki, M. Wiśniewski. Warszawa: Polskie Towarzystwo Współpracy z Klubem Rzymskim.

de Soto, H. (2002). Tajemnica kapitału. Dlaczego kapitalizm triumfuje na zachodzie, a zawodzi gdzie indziej, tłum. Sz. Czarnik. Warszawa: Fijorr Publishing.

Easterly, W. (2002). The Elusive Quest for Growth: Economists Advesntures and Disadventure in the Tropics. Boston: MIT Press.

Easterly, W. (2011). Measuring How and Why Aid Works - or Doesn't. The Wall Street Journal, 30.04.2011.

Easterly, W. (2009). The White Man's Burden: Why the West's Efforts to Aid to Rest Have Done So Much Ill and So Little Good. Oxford: Oxford University Press.

Golte, J., Adams, N. (1987). Caballos de Troya de los invasores, Lima: Instituto de Estudios Peruanos.

Kochanowska, K. (2013) Praca z rodziną w trzecim sektorze w Peru na przykładzie organizacji Coprodeli. Trzeci Sektor, nr specjalny 2013/2014. 
Komisja Europejska (2014). Sprawozdanie Komisji dla Parlamentu Europejskiego i Rady w sprawie spełnienia przez Peru właściwych kryteriów w kontekście negocjacji umowy o ruchu bezwizowym między Unia Europejska i Peru. Bruksela.

Łyniewska, A. (2010). Dlaczego Wenezuela stała w miejscu, kiedy Chile się rozwijało?, w: Zagadki wzrostu gospodarczego. Siły napędowe i kryzysy - analizy porównawcze, red. Balcerowicz, L., Rzońca, A. Warszawa: Wydawnictwo C.H. Beck.

Malthus, T. (2003). Prawo ludności, tłum. K. Stein. Warszawa: De Agostini Polska.

Meneses Rivas, M. (1974). La formacion de las barriadas en Lima Metropolitana 1945-1973. Lima: UNMSM.

Mirkowska-Ostatek, M. (2013). Oficjalna pomoc rozwojowa jako czynnik eliminujący skalę ubóstwa w państwach Trzeciego Świata, w: Polityka rozwojowa. Rola organizacji międzynarodowych w zwalczaniu ubóstwa na świecie, red. E. Latoszek, M. Proczek, Warszawa.

Moyo, D. (2009). Dead Aid: Why Aid Is Not Working and How There is Another Way for Africa. New York: Farrar Straus Giroux.

Moyo, D. (2009). Kaleka pomoc. Znak, 12.

Obłąkowska-Kubiak, K. (2014). Współpraca finansowa jednostek samorządu terytorialnego i organizacji pozarządowych w Polsce w realizacji zadania publicznego: kultura i ochrona dziedzictwa narodowego, w: Finansowanie działalności przedsiębiorstw a społeczna odpowiedzialność biznesu, red. A. Krzysztofek. Kraków: AT Wydawnictwo.

Polman, L. (2011). Karawana kryzysu, tłum. E. Jusewicz-Kalter. Wołowiec: Wydawnictwo Czarne.

Stowarzyszenie KLON/JAWOR (2002). Współpraca administracji publicznej i organizacji pozarzadowych $w$ dziedzinie ustug społecznych. Warszawa.

Strong, S. (1992). Shining Path:The World's Deadliest Revolutionary Force. Londyn: Harper Collins.

Śniadecka-Kolarska, M. (2006). Kobiety w migracjach przesiedleńczych w Peru (1980-2000). Środkowoeuropejskie Studia Polityczne, 1.

Ustawa z dnia 6 grudnia 2006 r. o zasadach prowadzenia polityki rozwoju, Dz. U. 2006, nr 227, poz. 1658 z późń. zm.

Węcławowicz, G. (2007). Geografia społeczna miast: zróżnicowania społeczno-przestrzenne. Warszawa: Wydawnictwa Naukowe PWN.

\section{Źródła internetowe}

Coprodeli USA, History in Peru, http://www.coprodeliusa.org/history, dostęp: 26.03.2019.

Coprodeli USA, Mission, Values, Vision, http://www.coprodeliusa.org/missionvision, dostęp: 26.03.2019.

Demographia, Demographia Word Urban Areas, 13th Annual Edition: 2017:04, s. 37, http:// demographia.com/db-worldua.pdf, dostęp: 26.03.2019.

Encyklopedia PWN, Peru. Ludność, http://encyklopedia.pwn.pl/haslo/Peru-Ludnosc;4574998. html, dostęp: 26.03.2019.

Instituto Nacional de Estadistica y Informatica, www.inei.gob.pe., dostęp: 26.03.2019. 
International Labour Organization, Key Indicators of the Labour Market, http://www.ilo.org/ global/statistics-and-databases/research-and-databases/kilm/, dostęp: 26.03.2019.

International Monetary Found, World Economic Outlook Database, http://www.imf.org/external/ pubs/ft/weo/ 2017/01/weodata/index.aspx, dostęp: 26.03.2019.

International Monetary Found, World Economic Outlook, April 2016, https://www.imf.org/ en/News/Articles/2016/11/18/SP111816-Peru-Seizing-Opportunities-in-a-Changing-Global-Economy, dostęp: 26.03.2019.

Ministerio de la Mujer y Poblaciones Vulnerables, Programas Nacionales, http://www.mimp. gob.pe, dostęp: 26.03.2019.

The World Bank, World Development Indicators, http://databank.worldbank.org/data/reports. aspx? source=2\&country=PER, dostęp: 26.03.2019.

The World Bank, GDP per capita, PPP (current international \$), https://data.worldbank.org/ indicator/ NY.GDP.PCAP.PP.CD?locations=PE, dostęp: 26.03.2019.

The World Bank, GDP groth (annual \%), https://data.worldbank.org/indicator/NY.GDP.MKTP. KD.ZG? end=2016\&locations=PE\&start=1990\&view=chart, dostęp: 26.03.2019.

The World Bank, GDP per capita (current US\$), https://data.worldbank.org/indicator/ NY.GDP. PCAP.CD?locations=PE, dostęp: 26.03.2019.

The World Bank, Development Research Group, http://iresearch.worldbank.org/PovcalNet/ index.htm, dostęp: 26.03.2019.

United Nations Development Programme, Trends in the Human Development Index, 1990-2015, http://hdr.undp.org/en/ composite/trends, dostęp: 26.03.2019.

Zygierewicz, A. (2019). Polityka humanitarna i rozwojowa Unii Europejskiej, http://orka.sejm. gov.pl/WydBAS.nsf/0/050F05FB26EC75E9C125779E0043DF6F/\$file/Polityka\%20rozwojowa\%20i\%20humanitarna.pdf, dostęp: 26.03.2019. 